\title{
Ga-doped Pt-Ni Octahedral Nanoparticles as a Highly Active and Durable Electrocatalyst for Oxygen Reduction Reaction
}

JeongHoon Lim, Hyeyoung Shin, MinJoong Kim, Hoin Lee, Kug-Seung Lee, YongKeun Kwon, DongHoon Song, SeKwon Oh, Hyungjun Kim, and EunAe Cho

Nano Lett., Just Accepted Manuscript • DOI: 10.1021/acs.nanolett.8b00028 • Publication Date (Web): 26 Mar 2018

Downloaded from http://pubs.acs.org on March 26, 2018

\section{Just Accepted}

"Just Accepted" manuscripts have been peer-reviewed and accepted for publication. They are posted online prior to technical editing, formatting for publication and author proofing. The American Chemical Society provides "Just Accepted" as a service to the research community to expedite the dissemination of scientific material as soon as possible after acceptance. "Just Accepted" manuscripts appear in full in PDF format accompanied by an HTML abstract. "Just Accepted" manuscripts have been fully peer reviewed, but should not be considered the official version of record. They are citable by the Digital Object Identifier (DOI®). "Just Accepted" is an optional service offered to authors. Therefore, the "Just Accepted" Web site may not include all articles that will be published in the journal. After a manuscript is technically edited and formatted, it will be removed from the "Just Accepted" Web site and published as an ASAP article. Note that technical editing may introduce minor changes to the manuscript text and/or graphics which could affect content, and all legal disclaimers and ethical guidelines that apply to the journal pertain. ACS cannot be held responsible for errors or consequences arising from the use of information contained in these "Just Accepted" manuscripts. 


\title{
Ga-doped Pt-Ni Octahedral Nanoparticles as a Highly Active and Durable Electrocatalyst for Oxygen Reduction Reaction
}

\author{
JeongHoon Lim ${ }^{1}$, Hyeyoung Shin ${ }^{2}$, MinJoong Kim ${ }^{1}$, Hoin Lee ${ }^{1}$, Kug-Seung Lee ${ }^{3}$, YongKeun \\ Kwon ${ }^{1}$, DongHoon Song ${ }^{1}$, SeKwon $\mathrm{Oh}^{1}$, and Hyungjun $\mathrm{Kim}^{4,5}$, EunAe Cho*1
}

\begin{abstract}
${ }^{1}$ Department of Materials Science and Engineering, Korea Advanced Institute of Science and Technology (KAIST), 291 Daehak-ro, Yuseong-gu, Daejeon, 34141, Republic of Korea ${ }^{2}$ Materials and Process Simulation Center (MSC), California Institute of Technology, Pasadena, California 91125, United States

${ }^{3}$ Pohang Accelerator Laboratory (PAL) \& National Institute for Nanomaterials Technology (NINT), Pohang University of Science and Technology (POSTECH), Pohang 790-784, Republic of Korea

${ }^{4}$ Graduate School of Energy, Environment, Water and Sustainability (EEWS), Korea Advanced Institute of Science and Technology (KAIST), 291 Daehak-Ro, Yuseong-Gu, Daejeon, 34141, Republic of Korea ${ }^{5}$ Department of Chemistry, Korea Advanced Institute of Science and Technology (KAIST), 291 Daehak-Ro, Yuseong-Gu, Daejeon, 34141, Republic of Korea
\end{abstract}

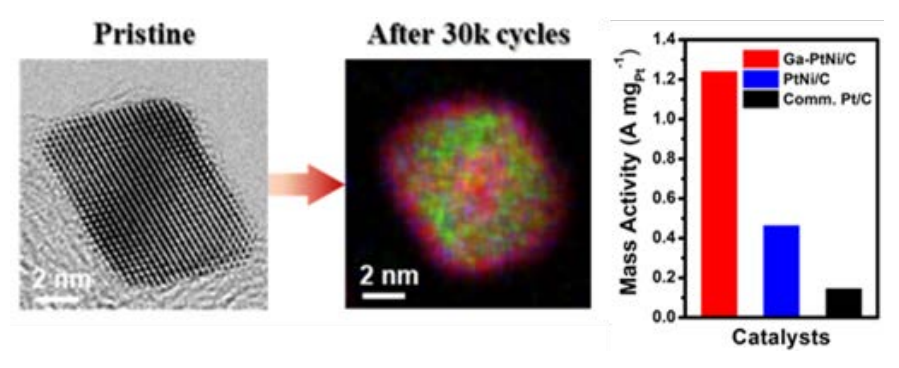

TOC Graphic 


\begin{abstract}
Bimetallic PtNi nanoparticles have been considered as a promising electrocatalyst for oxygen reduction reaction (ORR) in polymer electrolyte membrane fuel cells (PEMFCs) owing to their high catalytic activity. However, under typical fuel cell operating conditions, Ni atoms easily dissolve into the electrolyte, resulting in degradation of the catalyst and the membraneelectrode assembly (MEA). Here, we report gallium-doped PtNi octahedral nanoparticles on a carbon support (Ga-PtNi/C). The Ga-PtNi/C shows high ORR activity, marking an 11.7-fold improvement in the mass activity (1.24 $\mathrm{A} \mathrm{mg}_{\mathrm{Pt}}{ }^{-1}$ ) and a 17.3-fold improvement in the specific activity (2.53 $\left.\mathrm{mA} \mathrm{cm}^{-2}\right)$ compare to the commercial Pt/C (0.106 $\mathrm{A} \mathrm{mgPt}^{-1}$ and $\left.0.146 \mathrm{~mA} \mathrm{~cm}^{-2}\right)$. Density functional theory calculations demonstrate that addition of Ga to octahedral PtNi can cause an increase in the oxygen intermediate binding energy, leading to the enhanced catalytic activity toward ORR. In a voltage-cycling test, the $\mathrm{Ga}-\mathrm{PtNi} / \mathrm{C}$ exhibits superior stability to $\mathrm{PtNi} / \mathrm{C}$ and the commercial $\mathrm{Pt} / \mathrm{C}$, maintaining the initial Ni concentration and octahedral shape of the nanoparticles. Single cell using the Ga-PtNi/C exhibits higher initial performance and durability than those using the PtNi/C and the commercial Pt/C. The majority of the Ga-PtNi nanoparticles well maintain the octahedral shape without agglomeration after the single cell durability test (30,000 cycles). This work demonstrates that the octahedral Ga-PtNi/C can be utilized as a highly active and durable ORR catalyst in practical fuel cell applications.
\end{abstract}

Keywords: oxygen reduction reaction (ORR), gallium (Ga), PtNi octahedral, membraneelectrode assembly (MEA), polymer electrolyte membrane fuel cell (PEMFC) 


\section{INTRODUCTION}

Polymer electrolyte membrane fuel cells (PEMFCs) are the most attractive power source for zero-emission vehicles owing to their environmental friendliness, high energy efficiency, and high power density. However, their high cost and low durability have prevented PEMFCs from being fully implemented and commercialized, mainly due to the use of platinum as a catalyst ${ }^{1}$, 2 to overcome the sluggish kinetics of the oxygen reduction reaction (ORR) in the cathode. ${ }^{3,4}$ To reduce the use of Pt, extensive studies have been conducted and a large variety of ORR catalysts have been developed, such as Pt-M alloys $(\mathrm{M}=\mathrm{Ni}, \mathrm{Co}, \mathrm{Fe}, \mathrm{Cu}, \mathrm{Cr}, \mathrm{Mn}, \mathrm{Y} \text { etc. })^{5-10}$ as well as shape-controlled, ${ }^{11-15}$ dealloyed, ${ }^{16,17}$ and structurally ordered catalysts. ${ }^{18,}{ }^{19}$ Among them, Pt-M alloy catalysts have attracted much attention owing to their high intrinsic ORR activity and relatively simple synthesis process. ${ }^{20-23}$

In order to enhance the ORR activity of Pt-M alloy catalysts further, the shape-control strategy has been combined to expose a particular facet, which is favorable for the ORR. Most of all, PtNi octahedral nanoparticles ${ }^{24-28}$ with well-extended (111) facets exhibit significant improvements in the ORR activity which is 10-fold higher than that of Pt (111) and 90-fold higher than that of commercial Pt/C. ${ }^{20}$ However, the stability of these catalysts remains a critical issue because $\mathrm{Ni}$ atoms in PtNi nanoparticles can easily be dissolved into the electrolyte under detrimental corrosive fuel cell operating conditions and the octahedral shape of the PtNi nanoparticles becomes spherical with losing the (111) facets. To overcome these issues, recent studies have explored metal-doped PtNi octahedral catalysts. ${ }^{29-32}$ Beermann et al. reported that Rh-doped PtNi octahedral catalyst exhibited mass activity of $1.14 \mathrm{~A} \mathrm{mgPt}^{-1}$ at $0.9 \mathrm{~V}_{\mathrm{RHE}}$ initially and $0.32 \mathrm{~A} \mathrm{mget}^{-1}$ after 30k potential cycles. ${ }^{29}$ Huang et al. demonstrated that Mo-doped octahedral $\mathrm{Pt}_{3} \mathrm{Ni}$ nanoparticles supported on carbon had mass activity up to $6.98 \mathrm{~A} \mathrm{mgPt}^{-1}$ at 0.9 
$\mathrm{V}_{\mathrm{RHE}}$, with loss in the mass activity only by $5.5 \%$ during $8 \mathrm{k}$ potential cycles. ${ }^{30} \mathrm{Li}$ et al. showed size-controllable Fe-doped octahedral $\mathrm{Pt}_{3} \mathrm{Ni}$ nanoparticles, from 7 to $19 \mathrm{~nm}$ in size. The $13 \mathrm{~nm}$ Fe-Pt ${ }_{3} \mathrm{Ni} / \mathrm{C}$ exhibited the highest mass activity of $0.37 \mathrm{~A} \mathrm{mgPt}^{-1}$ at $0.9 \mathrm{~V}_{\mathrm{RHE}}$ and enhanced stability that showed around $25 \%$ loss in mass activity after $16 \mathrm{k}$ cycles. ${ }^{32}$

As reviewed above, various metal-doped PtNi octahedral catalysts have been reported to exhibit excellent ORR activity and stability. However, their activity and stability have been evaluated only through half-cell test not through single cell test. To assess the applicability of a new catalyst for PEMFCs, it is indispensable to fabricate a membrane-electrode assembly (MEA) using the catalyst and to evaluate single cell performance and durability of the MEA.5, ${ }^{33-35}$ In that sense, metal-doped PtNi octahedral nanoparticles have not yet been implemented in PEMFCs as a cathode catalyst.

Recent studies have reported gallium (Ga) has positive effects on activity of $\mathrm{Pt}$ and $\mathrm{Ni}$ catalyst for electrochemical reactions. Kumar et al. showed Ga-Pt intermetallic nanoparticles had higher catalytic activity toward ORR and methanol oxidation reaction than $\mathrm{Pt}^{36}$ Studt et al. presented Ni-Ga intermetallic compounds as stable candidates with good activity for reduction of $\mathrm{CO}_{2}$ to methanol. ${ }^{37}$ Meanwhile, Albiter et al. demonstrated that Ga could suppress dissolution of $\mathrm{Ni}$ in $\mathrm{H}_{2} \mathrm{SO}_{4}$ solution. ${ }^{38}$ All those results imply that Ga can modify electronic structure of Pt and Ni to improve their electrochemical catalytic activity and that Ga can stabilize $\mathrm{Ni}$ in the acidic environment. However, Ga has not been incorporated into PtNi nanoparticles for ORR.

In this study, we report Ga-doped PtNi octahedral nanoparticles on a carbon support (GaPtNi/C) that exhibit superior catalytic activity and stability in half-cell and single cell test as an ORR catalyst for PEMFCs. Electrochemical, chemical, and structural stability was thoroughly 
investigated through a harsh durability test. The effects of Ga doping on the surface properties of PtNi octahedral nanoparticles were examined by X-ray absorption fine structure (XAFS) analysis and density functional theory (DFT) calculation. To the best of our knowledge, we report for the first time Ga as a performance enhancing doping metal for PtNi ORR catalyst and a class of PtNi octahedral catalysts with excellent single cell performance and durability, demonstrating that the $\mathrm{Ga}-\mathrm{PtNi} / \mathrm{C}$ can be intactly utilized as a cathode catalyst for PEMFCs. 


\section{EXPERIMENTAL SECTION}

\section{Chemicals and Materials}

Platinum(II) acetylacetonate (Pt(acac)2, $97 \%$ ), nickel(II) acetylacetonate (Ni(acac)2, $95 \%$ ), gallium(III) acetylacetonate $\left(\mathrm{Ga}(\mathrm{acac})_{3}, \quad 99.99 \%\right.$ \%), ruthenium(III) acetylacetonate $\left(\mathrm{Ru}\left(\mathrm{C}_{5} \mathrm{H}_{7} \mathrm{O}_{2}\right)_{3}, 97 \%\right)$, zirconium(IV) acetylacetonate $\left(\mathrm{Zr}\left(\mathrm{C}_{5} \mathrm{H}_{7} \mathrm{O}_{2}\right)_{4}, 97 \%\right)$, gadolinium(III) acetylacetonate hydrate $\left(\mathrm{Gd}\left(\mathrm{C}_{5} \mathrm{H}_{7} \mathrm{O}_{2}\right)_{3} \cdot \mathrm{xH}_{2} \mathrm{O}, 99.9 \%\right)$, bismuth(III) acetate $\left(\left(\mathrm{CH}_{3} \mathrm{CO}_{2}\right)_{3} \mathrm{Bi}\right.$, $99.99 \%)$, zinc acetylacetonate hydrate $\left(\mathrm{Zn}\left(\mathrm{C}_{5} \mathrm{H}_{7} \mathrm{O}_{2}\right)_{2} \cdot \mathrm{xH}_{2} \mathrm{O}, 99.99 \%\right)$, lead(II) acetylacetonate $\left(\mathrm{Pb}\left(\mathrm{C}_{5} \mathrm{H}_{7} \mathrm{O}_{2}\right)_{2}, 99 \%\right)$, benzoic acid $\left(\mathrm{C}_{6} \mathrm{H}_{5} \mathrm{COOH}, \geq 99.5 \%\right)$, and N, N-dimethyl formamide (DMF, $\geq 99.9 \%$ ) were all obtained from Sigma-Aldrich. Vulcan XC-72R carbon powder used as support came from the Cabot Corporation. The commercial Pt/C catalyst used in this study (46 wt\%, 2-5 nm Pt NP) was purchased from Tanaka Company.

\section{Synthesis of PtNi and M-PtNi octahedral nanoparticles}

The PtNi octahedral nanoparticles on the carbon support (PtNi/C) were synthesized by onepot synthesis whereby all chemical materials were developed to $\mathrm{PtNi} / \mathrm{C}$ in one reactor as described below. ${ }^{30}$ The atomic ratio of platinum and nickel was determined to be $60: 40$ by adjusting the amounts of platinum(II) acetylacetonate (Pt(acac)2, $8 \mathrm{mg}$ ) and nickel(II) acetylacetonate (Ni(acac) $2,4 \mathrm{mg})$. Benzoic acid $\left(\mathrm{C}_{6} \mathrm{H}_{5} \mathrm{COOH}, 122 \mathrm{mg}\right)$ and Vulcan Carbon XC-72R (20 mg) were used as a shape-directing agent and catalyst support, respectively. The aforementioned chemical materials were dissolved in N, N-dimethylformamide (DMF, $10 \mathrm{~mL}$ ), and the mixture was dispersed by ultrasonication for 20 minutes, heated to $160{ }^{\circ} \mathrm{C}$ with vigorous stirring for $12 \mathrm{~h}$ in an oil bath, and cooled to room temperature. The resulting materials were collected by centrifugation twice with an ethanol/toluene mixture and once with an 
acetone/toluene mixture lastly. The final products were then dried in a vacuum oven at $50{ }^{\circ} \mathrm{C}$ for $12 \mathrm{~h}$.

To prepare metal-doped octahedral PtNi/C (M-PtNi/C, M: Ga, Ru, Zr, Gd, Bi, Zn and Pb), $20 \mathrm{mg}$ of the prepared PtNi/C nanoparticles were dispersed in $10 \mathrm{~mL}$ of DMF and a small amount of corresponding metal precursor was added to the dispersion. The amount of doping metal in the dispersion was determined to be 3 at \% among Pt and $\mathrm{Ni}$ atomic compositions. Then, the mixture was sonicated for $20 \mathrm{~min}$ and heated to $170{ }^{\circ} \mathrm{C}$ for $48 \mathrm{~h}$ in an oil bath and cooled to room temperature with stirring. All resulting materials were collected by centrifugation twice with the ethanol/toluene mixture and with the acetone/toluene mixture. The final products were dried in a vacuum oven at $50{ }^{\circ} \mathrm{C}$ for $12 \mathrm{~h}$.

\section{Characterization of the nanoparticles}

Cs-corrected transmission electron microscopy (TEM, Titan cubed G2 60-300, $300 \mathrm{kV}$ ) and high-angle annular dark-field scanning transmission electron microscopy (HAADF-STEM) images were acquired to analyze the morphology and crystal structure of the Ga-PtNi/C and PtNi/C. Energy dispersive X-ray (EDX) spectroscopy was performed on a Cs-corrected TEM to examine the elemental distributions and chemical compositions in the PtNi octahedral nanoparticles. The chemical compositions of all catalysts were confirmed by inductively coupled plasma optical emission spectroscopy (ICP-OES). X-ray powder diffraction patterns were collected using $\mathrm{Cu}-\mathrm{K} \alpha$ radiation. X-ray photoelectron spectroscopy (XPS) analysis was performed to examine the oxidation states of Pt and Ni on the surfaces of the nanoparticles. Xray absorption fine structure (XAFS) was measured at the 8C nano-probe XAFS beamline (BL8C) of the Pohang Light Source (PLS-II) in a $3.0 \mathrm{GeV}$ storage ring with a ring current of 
$360 \mathrm{~mA}$. The radiation source of BL8C is a tapered in-vacuum-undulator. XAFS spectra were gathered in both transmission and fluorescence modes. Extended x-ray absorption fine structure (EXAFS) spectra were fitted in a Fourier-transform range of $3 \sim 10 \AA^{-1}$ with a Hanning window applied between $1 \AA$ and $3.2 \AA$. Theoretical models for the EXAFS fits were constructed by adding shells of atoms around the central atom in the Pt fcc structure.

\section{Electrochemical measurements}

The electrocatalytic activity and stability were evaluated using a potentiostat (Pine instrument) with a standard three-electrode electrochemical cell. A Pt mesh and Ag/AgCl were used as a counter electrode and as a reference electrode, respectively. All potentials were converted to a reversible hydrogen electrode (RHE). To prepare the catalyst inks, catalyst powders and $20 \mu \mathrm{L}$ of a $5 \mathrm{wt} \%$ Nafion solution (1100 EW, DuPont) were dissolved in $0.5 \mathrm{~mL}$ of D.I. water and $0.5 \mathrm{~mL}$ of isopropyl alcohol (Sigma Aldrich). After ultrasonication for 10 minutes, the well-dispersed ink was coated onto the surface of a glassy carbon electrode (GCE). The Pt loading amounts of all catalysts on the GCEs were $25 \mu \mathrm{g}_{\mathrm{Pt}} / \mathrm{cm}^{2}$, and the fine films on the surfaces of the GCEs were formed at $50{ }^{\circ} \mathrm{C}$ for 10 minutes in oven.

The electrochemical active surface area (ECSA) was obtained by hydrogen under potential deposition and CO stripping method. Cyclic voltammograms (CVs) were measured in an Arsaturated 0.1 $\mathrm{M} \mathrm{HClO}_{4}$ solution with a scan rate of $100 \mathrm{mV} \mathrm{s}^{-1}$ at room temperature. ECSAs were calculated by integrating the hydrogen adsorption/desorption charge area between 0.05 and $0.35 \mathrm{~V}_{\mathrm{RHE}}$ from the CVs. The charge density for the adsorption of one monolayer hydrogen on $\mathrm{Pt}\left(\mathrm{Q}_{\mathrm{H}}\right)$ was assumed to be $210 \mu \mathrm{C} \mathrm{cm}^{-2} .{ }^{39}$ For $\mathrm{CO}$ stripping experiments, $\mathrm{CO}$ gas was purged into the electrolyte with applying a potential of $0.05 \mathrm{~V}$ to the electrode for $5 \mathrm{~min}$. Then, Ar gas 
was fed to remove CO from the electrolyte and the CV curves were collected between 0.05 and 1.2 $\mathrm{V}_{\mathrm{RHE}}$ with a sweep rate of $50 \mathrm{mV} \mathrm{s}^{-1}$.

The ORR polarization curves were measured in an $\mathrm{O}_{2}$-saturated $0.1 \mathrm{M} \mathrm{HClO}_{4}$ solution using a scan rate of $10 \mathrm{mV} \mathrm{s}^{-1}$ at $1600 \mathrm{rpm}$. To obtain the kinetic current $\left(\mathrm{I}_{\mathrm{k}}\right)$, the following equation was used,

$\frac{1}{\mathrm{I}}=\frac{1}{\mathrm{I}_{\mathrm{k}}}+\frac{1}{\mathrm{I}_{\mathrm{d}}}$

where the current (I) was measured at $0.9 \mathrm{~V}_{\mathrm{RHE}}$ and the diffusion limiting current $\left(\mathrm{I}_{\mathrm{d}}\right)$ was determined in the diffusion-limited current area.

An accelerated stress test (AST) was performed in $\mathrm{O}_{2}$-saturated $0.1 \mathrm{M} \mathrm{HClO}_{4}$ solution via voltage-cycling between 0.6 and $1.1 \mathrm{~V}_{\mathrm{RHE}}$ at a scan rate of $50 \mathrm{mV} \mathrm{s}^{-1}$. CVs and ORR polarization curves were measured after $4 \mathrm{k}, 8 \mathrm{k}, 12 \mathrm{k}$, and $30 \mathrm{k}$ voltage cycles. 


\section{Single-cell tests}

To evaluate the performance and durability of the catalysts in single cells, membraneelectrode assemblies (MEAs) were fabricated. As the cathode catalyst, Ga-PtNi/C, PtNi/C and commercial Pt/C were employed and $\mathrm{Pt} / \mathrm{C}$ was used for the anode. Catalyst inks were prepared by mixing/dispersing the catalysts $(10.1 \mathrm{mg} / \mathrm{mL})$ and a Nafion ionomer solution (5 wt\%, Sigma Aldrich) (4.3 mg/mL) in isopropyl alcohol. The prepared catalyst ink was sonicated in an ultrasonic bath for 20 min and sprayed directly onto a Nafion 211 membrane (DuPont). The Pt loading was $0.15 \mathrm{mg}_{\mathrm{Pt}} \mathrm{cm}^{-2}$ for both the anode and the cathode. The active electrode area was $5 \mathrm{~cm}^{2}$. The fabricated MEAs were assembled with gas diffusion layers (GDL, JNTG-20-A3), gaskets, bipolar plates and current collectors (Pt-coated brass). The single cells were operated at $65{ }^{\circ} \mathrm{C}$ and $1 \mathrm{~atm}$ without backpressure. Fully humidified hydrogen and air were supplied to the anode and cathode, respectively. The flow rates of hydrogen and air were 209 and $663 \mathrm{~mL}$ $\min ^{-1}$, respectively. To assess the durability, triangle voltage cycling tests were carried out between 0.6 and $1.0 \mathrm{~V}$ at a sweep rate of $50 \mathrm{mV} \mathrm{s}^{-1}$ while feeding fully humidified hydrogen (20 $\left.\mathrm{mL} \mathrm{min}^{-1}\right)$ and nitrogen $\left(100 \mathrm{~mL} \mathrm{~min}^{-1}\right)$ to the anode and cathode, respectively. After 3k, 10k, 15k, and 30k cycles, polarization curves were measured under conditions identical to those described above. 


\section{RESULTS AND DISCUSSION}

To develop a highly active and durable catalyst for oxygen reduction reaction (ORR), we synthesized PtNi octahedral nanoparticles supported on carbon (PtNi/C) and incorporated various metals onto the surfaces of the PtNi octahedral nanoparticles (M-PtNi/C, $M=\mathrm{Ga}, \mathrm{Ru}$, $\mathrm{Zr}, \mathrm{Gd}, \mathrm{Bi}, \mathrm{Zn}, \mathrm{Pb})$. Table S1 summarizes the chemical compositions of the $\mathrm{PtNi} / \mathrm{C}$ and $\mathrm{M}-$ $\mathrm{PtNi} / \mathrm{C}$ as measured by ICP-OES. The atomic ratio of Pt to Ni was $1.7 \sim 2.0$ and the Pt loading on the carbon support was about 14 wt\%. Powder X-ray diffraction (XRD) patterns for the prepared catalysts (Figure 1a and Figure S1) were well matched with those of the fcc structure of Pt with higher $2 \theta$ angles, revealing the alloy formation of Ni with Pt.

The ORR polarization curves of the prepared catalysts were measured in an $\mathrm{O}_{2}$-saturated 0.1 $\mathrm{M} \mathrm{HClO}_{4}$ electrolyte with a sweep rate of $10 \mathrm{mV} \mathrm{s}^{-1}$ and rotation of $1600 \mathrm{rpm}$ at room temperature. Figure S2 shows that the ORR activity of the synthesized $\mathrm{PtNi} / \mathrm{C}\left(0.464 \mathrm{~A} \mathrm{mg}_{\mathrm{Pt}}{ }^{-1}\right.$ @ $\left.0.9 \mathrm{~V}_{\mathrm{RHE}}\right)$ was 4.4 times higher than that of the commercial Pt/C (0.106 $\left.\mathrm{A} \mathrm{mg}_{\mathrm{Pt}^{-1}} @ 0.9 \mathrm{~V}_{\mathrm{RHE}}\right)$. Remarkably, the incorporation of a small amount (0.2 2.5 at \%) of M had profound effects on the ORR activity of the PtNi/C catalyst. Among the prepared catalysts, Ga-PtNi/C exhibited outstanding ORR activity (1.24 A mg ${ }_{\mathrm{Pt}}{ }^{-1} @ 0.9 \mathrm{~V}_{\mathrm{RHE}}$ ), which was an 11.7-fold enhancement in comparison with Pt/C.

The electrochemical surface areas (ECSAs) of the Ga-PtNi/C, PtNi/C, and commercial Pt/C were measured using hydrogen under potential deposition (HUPD) and a CO stripping method. For HUPD, cyclic voltammetry (CV) was conducted in an Ar-saturated $0.1 \mathrm{M} \mathrm{HClO}_{4}$ electrolyte with a sweep rate of $100 \mathrm{mV} \mathrm{s}^{-1}$ at room temperature, as presented in Figure 1b. ECSA values were calculated from the hydrogen adsorption/desorption charge in the potential 
region from 0.05 to $0.35 \mathrm{~V}_{\mathrm{RHE}}$ after double-layer correction. The octahedral Ga-PtNi/C and $\mathrm{PtNi} / \mathrm{C}$ exhibited identical ECSAs of $49 \mathrm{~m}^{2} \mathrm{gPt}^{-1}$. The ECSA of the commercial Pt/C was $74 \mathrm{~m}^{2}$ $\mathrm{gPt}^{-1}$. From the CO stripping experiments, the ECSAs were estimated to be $53 \mathrm{~m}^{2} \mathrm{gPt}^{-1}$ for Ga$\mathrm{PtNi} / \mathrm{C}$ and $\mathrm{PtNi} / \mathrm{C}$ and $78 \mathrm{~m}^{2} \mathrm{~g}_{\mathrm{Pt}}{ }^{-1}$ for commercial Pt/C (Figure S3 and Table S3). Compared to commercial Pt/C, the Ga-PtNi/C and PtNi/C exhibited lower ECSA values according to both HUPD and CO stripping, most likely due to the larger particle sizes (Figure 2 and Figure S5). Based on the mass activity at $0.9 \mathrm{~V}_{\mathrm{RHE}}$ and the ECSA from HUPD, the specific activity of Ga$\mathrm{PtNi} / \mathrm{C}, \mathrm{PtNi} / \mathrm{C}$, and commercial Pt/C were calculated to be 2.53, 0.947, and $0.146 \mathrm{~mA} \mathrm{~cm}{ }^{-2}$, respectively.

High-resolution transmission electron microscopy (HRTEM) images of Ga-PtNi/C and PtNi/C (Figure 2) revealed, in both samples, that the octahedral nanoparticles were uniformly distributed on the carbon support with an average edge length of $6.0 \pm 0.4 \mathrm{~nm}$. In both samples, individual particles had a single-crystal structure with a $0.22 \mathrm{~nm}$ edge lattice spacing, which is consistent with well-extended $f c c$ (111) facets of $\mathrm{Pt}_{3} \mathrm{Ni}$. The lattice spacing of the (111) plane calculated from the XRD results (Figure 1a and Table S2) using Vegard’s law were 0.220 and $0.222 \mathrm{~nm}$ for Ga-PtNi/C and PtNi/C, respectively. X ray-photoelectron spectroscopy (XPS) confirmed the presence of Pt and Ni in the samples (Figure S4). The Pt $4 \mathrm{f}$ and Ni 2p peaks of Ga-PtNi/C and PtNi/C revealed that most of the surface Pt was in a metallic state and that most of the surface Ni is in an oxidized state. The Ga 3d peaks exhibit that Ga was in a metallic state and $\mathrm{Ga}^{3+}$ state. Surface concentration of Ga in Ga-PtNi measured from the XPS results was 15.9 at\%. Considering that Ga concentration obtained by ICP-OES was 1.4 at\% and that Ga was doped onto the prepared PtNi nanoparticles, most of Ga atoms are sitting on the surface of the PtNi octahedral nanoparticles. 


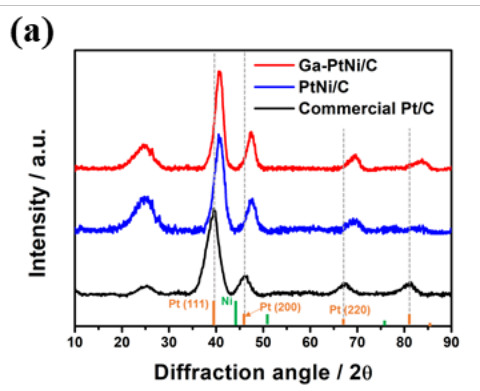

(b)

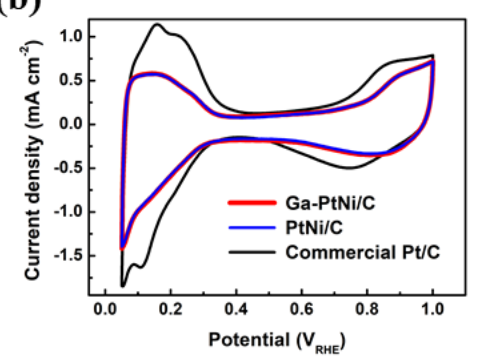

(c)

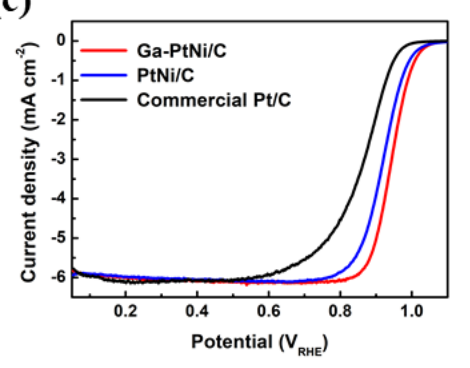

Figure 1. (a) XRD patterns Ga-PtNi/C, PtNi/C and commercial Pt/C. (b) Cyclic voltammograms of Ga-PtNi/C, PtNi/C, and commercial Pt/C recorded in an Ar-saturated $0.1 \mathrm{M} \mathrm{HClO}_{4}$ solution with $100 \mathrm{mV} \mathrm{s}^{-1}$ at room temperature. (c) ORR polarization curves of Ga-PtNi/C, PtNi/C, and commercial Pt/C recorded in an $\mathrm{O}_{2}$-saturated $0.1 \mathrm{M} \mathrm{HClO}_{4}$ solution with $10 \mathrm{mV} \mathrm{s}^{-1}$ and $1600 \mathrm{rpm}$ at room temperature.
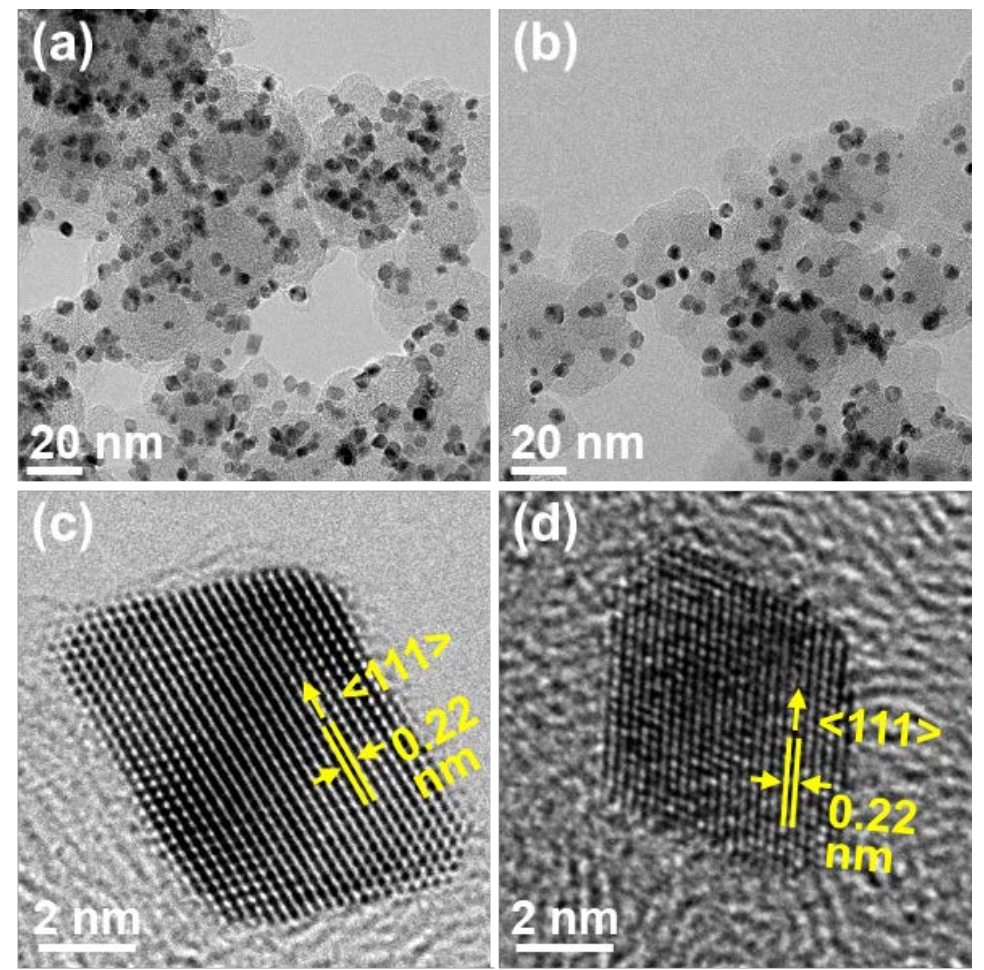

Figure 2. TEM images of (a) Ga-PtNi/C and (b) PtNi/C nanoparticles. HRTEM images of individual (c) Ga-PtNi/C and (d) PtNi/C nanoparticle. 
Although various PtNi nanoparticles have exhibited excellent ORR activity, ${ }^{12,}$ 27, 40 stability issues have limited their applications to fuel cells. It is well known that under the operating conditions of fuel cells, the dissolution of $\mathrm{Ni}$ into the electrolyte results in degradation of catalyst and membrane-electrode assemblies (MEAs). ${ }^{41,} 42$ In addition, shape-controlled catalysts have a tendency to become spherical in shape with reducing surface energy of the nanoparticles. ${ }^{27,} 43$ To investigate the stability of the octahedral Ga-PtNi/C and $\mathrm{PtNi} / \mathrm{C}$, an accelerated stress test (AST) was conducted between 0.6 and $1.1 \mathrm{~V}_{\mathrm{RHE}}$ in an $\mathrm{O}_{2}$-saturated 0.1 $\mathrm{M} \mathrm{HClO}_{4}$ solution at a scan rate of $50 \mathrm{mV} \mathrm{s}^{-1}$, which is regarded as an extremely harsh condition (Table S4). Ga-PtNi/C showed outstanding stability compared to PtNi/C and even commercial Pt/C (Figure 3 and Figure S5). During potential cycling, the ECSA of Ga-PtNi/C increased slightly from 49 to $53 \mathrm{~m}^{2} \mathrm{gPt}^{-1}$ at $12 \mathrm{k}$ cycles and then decreased to $44 \mathrm{~m}^{2} \mathrm{gPt}^{-1}$ at $30 \mathrm{k}$ cycles (Figure 3e). The ECSA of PtNi/C increased to $65 \mathrm{~m}^{2} \mathrm{gPt}^{-1}$ at $4 \mathrm{k}$ and then decreased to $28 \mathrm{~m}^{2} \mathrm{gPt}^{-}$ ${ }^{1}$ at $30 \mathrm{k}$ cycles. The initial increases in the ECSA of both catalysts could be attributed to the dissolution of $\mathrm{Ni}$ atoms from PtNi nanoparticles and the resulting exposure of Pt atoms onto the surface layer. ${ }^{44}$ After $30 \mathrm{k}$ cycles, Ga-PtNi/C retained mass activity of $0.428 \mathrm{~A} \mathrm{mgPt}^{-1}$. In contrast, the mass activity levels of PtNi/C and Pt/C substantially decreased to 0.009 and 0.019 $\mathrm{m}^{2} \mathrm{gPt}^{-1}$, respectively. Thus, it can be concluded that the incorporation of Ga onto the PtNi surface effectively suppressed the dissolution of Ni atoms from the nanoparticles, resulting in enhanced stability of Ga-PtNi/C. The specific activities (Figure 3g) showed similar trends over the potential cycles to those of the mass activities. 
(a)

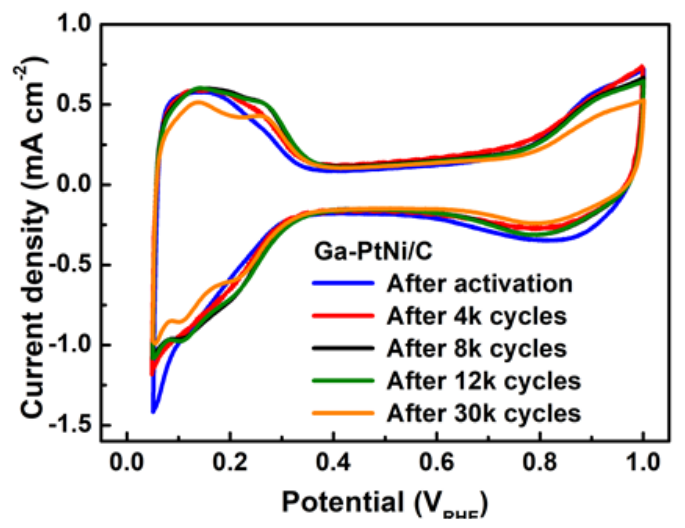

(c)

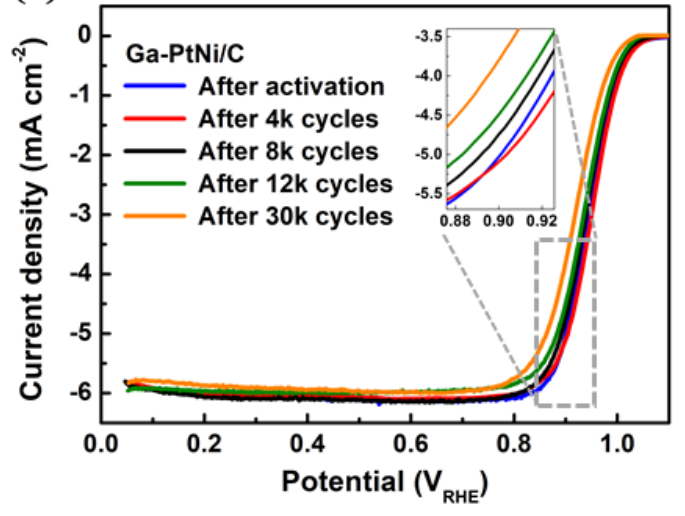

(b)

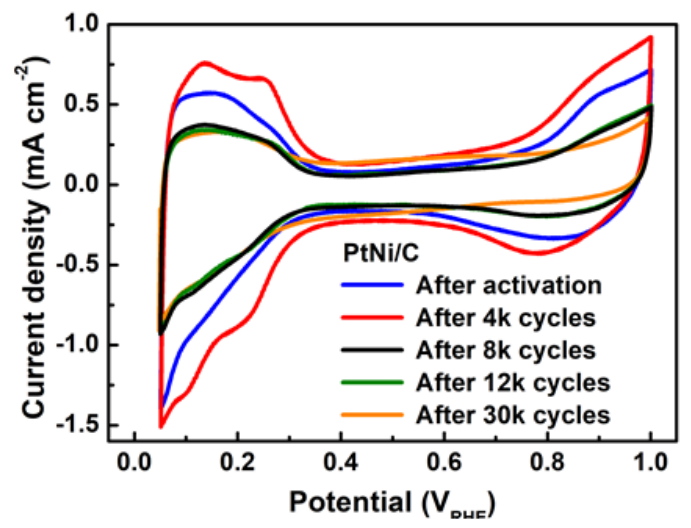

(d)

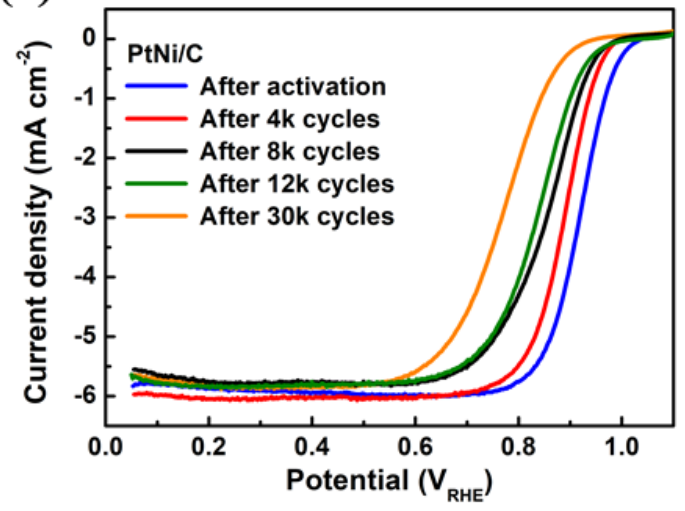

(e)

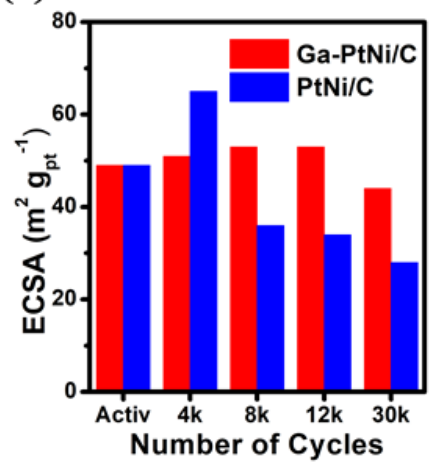

(f)

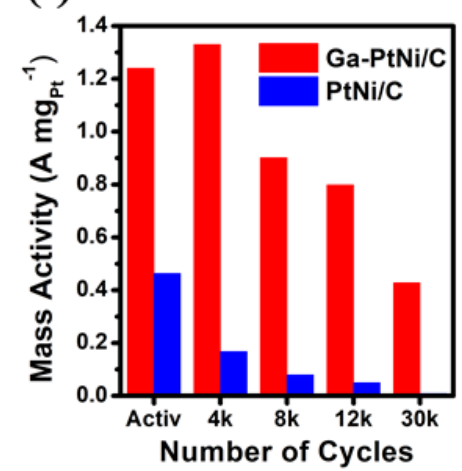

(g)

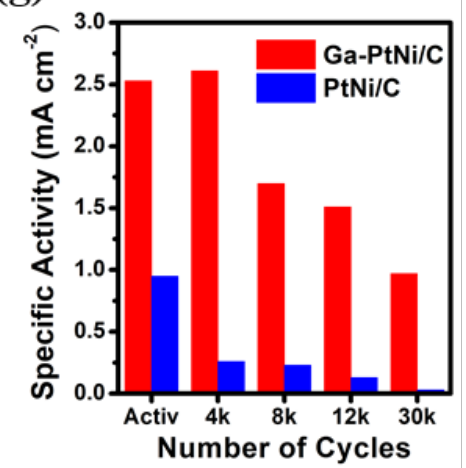

Figure 3. Electrochemical stability of Ga-PtNi/C and PtNi/C. Cyclic voltammograms of (a) Ga-PtNi/C and (b) PtNi/C and ORR polarization curves of (c) Ga-PtNi/C and (d) PtNi/C measured before and after $4 \mathrm{k}, 8 \mathrm{k}, 12 \mathrm{k}$ and 30k cycles. (e) Electrochemical surface area (ECSA), (f) mass activity and (g) specific activity at 0.9 V $\mathrm{RHE}$ for Ga-PtNi/C and PtNi/C. 
To examine the effects of the potential cycles on the morphology and chemical composition of the Ga-PtNi/C and PtNi/C, HRTEM, STEM, EDX, and elemental line scanning were carried out before and after 4k, 8k, 12k, and 30k cycles (Figure 4 and S6). The HRTEM and STEM images revealed that the majority of the Ga-PtNi nanoparticles maintained the octahedral shape after 30k cycles, while the PtNi nanoparticles became spherical in shape after only 4k cycles. Elemental mapping images and line scanning profiles (Figure 4) demonstrate that $\mathrm{Pt}, \mathrm{Ni}$, and Ga were homogeneously distributed throughout the surfaces of the octahedral Ga-PtNi nanoparticles up to $12 \mathrm{k}$ cycles. After $30 \mathrm{k}$ cycles, a Pt-rich surface layer was observed with Ni atoms in the inner region of Ga-PtNi. Although the surface $\mathrm{Ni}$ atoms were dissolved, the $\mathrm{Ni}$ content in Ga-PtNi nanoparticles as determined from EDX (Figure 4 and S7) remained at 30 at \% (initially 38 at \%) with maintaining 1.9 at \% Ga. In contrast, the Ni content decreased from 40 to 10 at \% in PtNi nanoparticles during 30k cycles. After 30k cycles, the concentrations of the metal ions in the electrolyte were measured by ICP-MS (Table S5). Pt and Ni concentrations in the aged electrolyte were clearly lower for $\mathrm{Ga}-\mathrm{PtNi} / \mathrm{C}$ than for $\mathrm{PtNi} / \mathrm{C}$. Adding Ga to PtNi nanoparticles inhibited the dissolution of Ni as well as Pt. Meanwhile, the commercial $\mathrm{Pt} / \mathrm{C}$ also underwent severe agglomeration during 30k potential cycles under identical AST conditions (Figure S5). All of these results demonstrate that a small amount of Ga incorporated onto the surface of PtNi nanoparticles effectively prevents the dissolution of Pt and Ni from PtNi nanoparticles and the collapse of the preferential octahedral shape, contributing to the excellent electrochemical stability of the Ga-PtNi/C catalyst, as discussed above. 


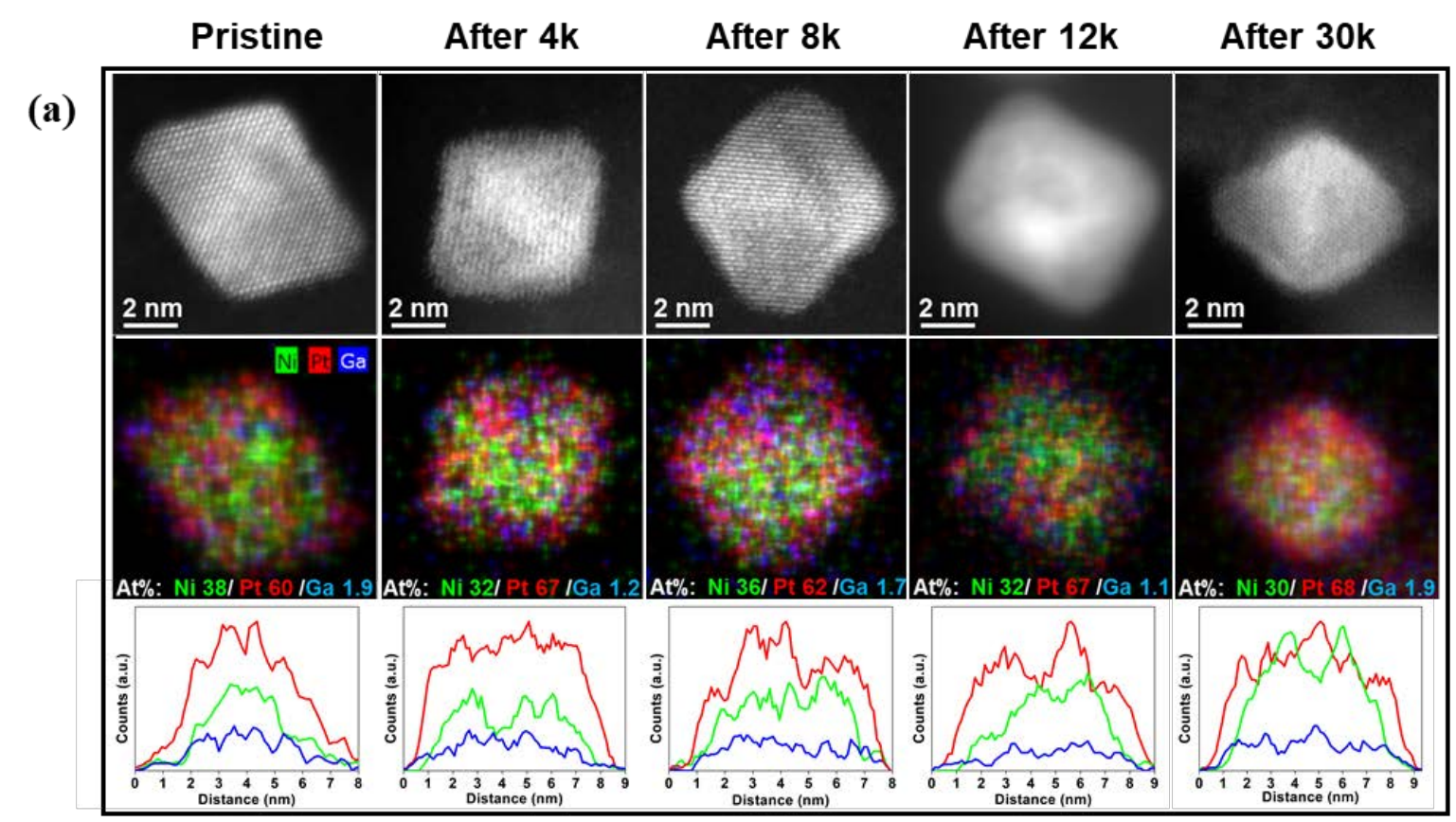

(b)

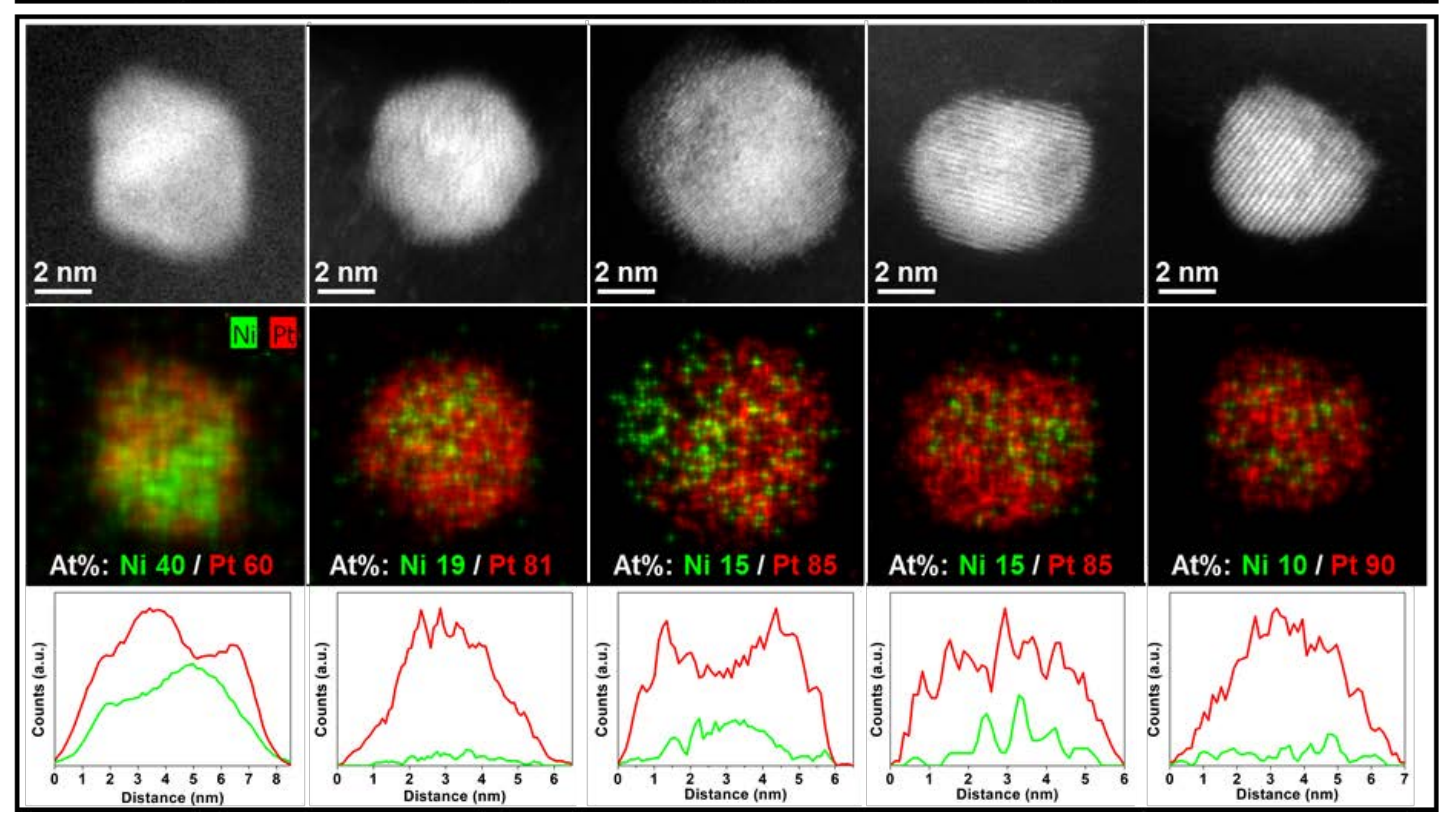

Figure 4. HAADF STEM images with EDX analyses and line scanning profiles of (a) Ga$\mathrm{PtNi} / \mathrm{C}$ and (b) PtNi/C during the voltage-cycling tests. The composition changes of $\mathrm{Ni}, \mathrm{Pt}$, and Ga atoms in the nanoparticles were determined by EDX (inset in the EDX mapping results). Pt (red), Ni (green), and Ga (blue) line scanning profiles of the nanoparticles were measured at pristine, $4 \mathrm{k}, 8 \mathrm{k}, 12 \mathrm{k}$, and $30 \mathrm{k}$ cycles. 
$\mathrm{X}$-ray adsorption near-edge structure (XANES) spectroscopy and the extended X-ray absorption fine structure (EXAFS) were analyzed to investigate the oxophilicity, electronic structure, and Pt-Pt interatomic distances of the Ga-PtNi/C, PtNi/C, and commercial Pt/C (Figure 5a, Figure S8, and Table S6). In the XANES spectra, the white line peak intensity is associated with electronic transition from the core $2 \mathrm{p}_{2 / 3}$ orbital to the unoccupied $5 \mathrm{~d}$ orbitals for the Pt L3 edge and the degree of oxidation of Pt as well. ${ }^{45-47}$ As presented in Figure 5a, the Ga-PtNi/C showed the lowest white line peak intensity, indicating the less-oxidized status of Pt compared to the statuses of PtNi/C and commercial Pt/C. Given that oxidized Pt is less active toward ORR than metallic Pt, the less oxidized Pt could enhance the oxygen reduction kinetics and stabilize the catalysts during the voltage-cycling process. ${ }^{48,} 49$ The EXAFS analysis revealed that the Pt-Pt and Pt-Ni distances in the PtNi nanoparticles were slightly reduced by Ga doping (Table S6). The XRD results shown in Figure 1a and Table S2 confirm that the incorporation of Ga onto the surfaces of PtNi octahedral nanoparticles induced compressive strain in the structure by reducing the lattice constant. Lattice compression by a doping element has been observed for Mo-doped and Rh-doped octahedral PtNi. ${ }^{29,} 50$

Density functional theory (DFT) calculations were employed to understand the effects of Ga doping on the ORR activity of PtNi octahedral nanoparticles. As a descriptor for the ORR activity, ${ }^{51}$ the oxygen intermediate binding energy $\left(\Delta \mathrm{E}_{0}\right)$ was calculated for Ga-PtNi, PtNi and Pt slab models, respectively (see Supporting Information for details). It is of noted that GaPtNi and PtNi slab model is covered with a Pt skin layer as shown in Figure 5b. DFT calculations show that both applying compressive strain and alloying Pt with Ni (at an atomic ratio of 2:1) lower the $\Delta$ Eo. Figure $5 c$ reveals linear decrease in the $\Delta \mathrm{E}$ in both $\mathrm{Pt}$ and $\mathrm{PtNi}$ alloy with compressive strain induced by the incorporation of $\mathrm{Ni}$ and $\mathrm{Ga}$ atoms onto Pt. 
Furthermore, alloying Pt with $\mathrm{Ni}$ also weakens the interaction with oxygen intermediates as we can see by comparing black dot at Pt lattice spacing and blue dot at PtNi lattice spacing as shown in Figure 5c, in accordance with an earlier result on $\mathrm{Pt}_{3} \mathrm{Ni}$ alloys. ${ }^{22}$ On the contrary to the compressive strain effect and alloying effect with $\mathrm{Ni}$, we found that the presence of $\mathrm{Ga}$ on the surface of PtNi makes the $\Delta$ Eo stronger, approaching to the optimal $\Delta$ Eo for maximum ORR activity (the highlighted regime with dotted line in Figure 5d, which is expected to show better activity than Pt). Figure $5 \mathrm{~d}$ shows the tendency to increase the $\Delta \mathrm{Eo}$ with increasing $\mathrm{Ga}$ dopant coverage on the PtNi. These results demonstrate that Ga doping effectively improves the ORR activity of PtNi by locally enhancing $\Delta$ Eo as well as stability by making the surface less oxophilic in overall due to the compressive strain induced by Ga doping. In addition, we analyzed the total amount of electron loss and core-level energy shift of Pt and Ni next to Ga on the surface of Ga-PtNi/C. As shown in Figure S9, we found that both Pt and Ni become electron-rich (the number of electron loss decreases and core-level energy increases) and less oxidized as Ga contents within the system increase. We believe that the incorporation of Ga onto the PtNi surface effectively suppresses the oxidation of both Pt and $\mathrm{Ni}$ and thus the dissolution of both Pt and Ni from the nanoparticles decreases, which results in enhancing stability of Ga-PtNi/C, compared to PtNi. 
(a)

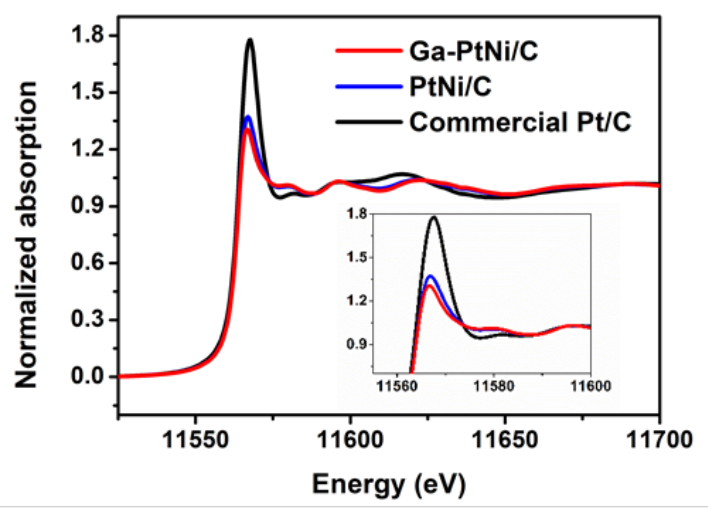

(b)

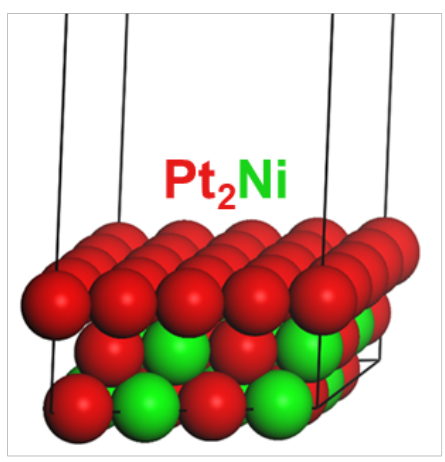

(d)

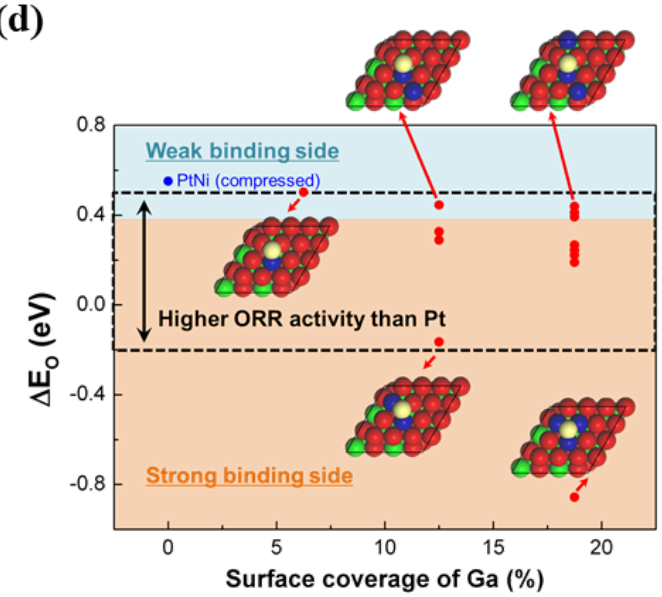

Figure 5. (a) Pt L3 XANES analysis of Ga-PtNi/C, PtNi/C, and commercial Pt/C. (b) Atomic structure of a PtNi (111) slab model. The oxygen intermediate binding energy $\left(\Delta \mathrm{E}_{\mathrm{o}}\right)$ as a function of (c) the compressive strain and (d) the surface coverage of Ga. The inset shows top views of each surface model. Red, green, blue and white atoms represent $\mathrm{Pt}, \mathrm{Ni}, \mathrm{Ga}$, and $\mathrm{O}$ atoms, respectively. 
Figure 6 presents the single-cell performance with the Ga-PtNi/C, PtNi/C, and commercial $\mathrm{Pt} / \mathrm{C}$ as a cathode catalyst. The single cells were operated at $65{ }^{\circ} \mathrm{C}$ on fully humidified $\mathrm{H}_{2}$ and air at $1 \mathrm{~atm}$. The Pt loadings for both the anode and the cathode were $0.15 \mathrm{mg} \mathrm{cm}^{-2}$. At a cell voltage of $0.6 \mathrm{~V}$, the single cell with Ga-PtNi/C exhibited current density of $700 \mathrm{~mA} \mathrm{~cm}^{-2}$ and power density of $420 \mathrm{~mW} \mathrm{~cm}{ }^{-2}$, both higher than those of PtNi/C $\left(639 \mathrm{~mA} \mathrm{~cm}{ }^{-2}\right.$ and $383 \mathrm{~mW}$ $\mathrm{cm}^{-2}$ ) and commercial Pt/C (552 $\mathrm{mA} \mathrm{cm}^{-2}$ and $331 \mathrm{~mW} \mathrm{~cm}^{-2}$, Table 1).

After $15 \mathrm{k}$ potential cycles between 0.6 and $1.0 \mathrm{~V}$, the performance of a single cell using GaPtNi/C decreased by $12 \%$ in terms of the current density at $0.6 \mathrm{~V}$ (700 to $615 \mathrm{~mA} \mathrm{~cm}^{-2}$ ), whereas that of PtNi/C was decreased by $31 \%$ (639 to $441 \mathrm{~mA} \mathrm{~cm}^{-2}$ ) while in the commercial $\mathrm{Pt} / \mathrm{C}$ the decline $39 \%$ (552 to $335 \mathrm{~mA} \mathrm{~cm}^{-2}$ ). After 30k cycles, the single cell of Ga-PtNi/C exhibited a current density of $469 \mathrm{~mA} \mathrm{~cm}^{-2}$ at $0.6 \mathrm{~V}$ while those of the $\mathrm{PtNi} / \mathrm{C}$ and commercial $\mathrm{Pt} / \mathrm{C}$ showed outcomes of 378 and $239 \mathrm{~mA} \mathrm{~cm}^{-2}$, respectively. To investigate the degradation of the catalysts, the single cells were disassembled after 30k cycles and the used catalysts were collected and observed using TEM. The commercial Pt/C revealed severe agglomeration of the Pt nanoparticles. The PtNi/C showed spherically shaped $\mathrm{PtNi}$ nanoparticles and serious agglomeration as well. In contrast, the Ga-PtNi nanoparticles were still well dispersed on the carbon support, and a considerable number of Ga-PtNi nanoparticles retained their octahedral shape (Figure S10). It was reported that Pt atoms diffuse to the surface in Pt-Ni alloys to deform the initial octahedral shape of the alloy nanoparticles ${ }^{28,29}$ and the surface segregation energy of Pt is affected by some elements doped on Pt-Ni alloy surface. ${ }^{29,52}$ Thus, the excellent stability of Ga-PtNi octahedral nanoparticles could be associated with the increase in surface segregation energy of Pt by Ga-doping. In addition, Ni-Ga catalysts exhibited stable 
electrocatalytic activity ${ }^{37,53}$ and Ga reduced dissolution of $\mathrm{Ni}$ in acidic solution, ${ }^{38}$ implying that Ga doping could stabilize Ni by suppressing Ni dissolution, contributing to the improvement of stability of the PtNi octahedral nanoparticles. The excellent initial and long-term single cell performance of the Ga-doped PtNi/C demonstrates that the octahedral Ga-PtNi/C prepared in this study can be intactly utilized as a cathode catalyst for PEMFCs. 
(a)

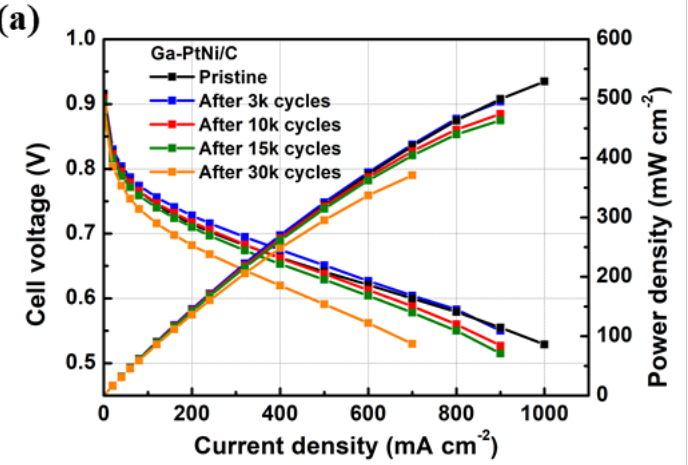

(c)

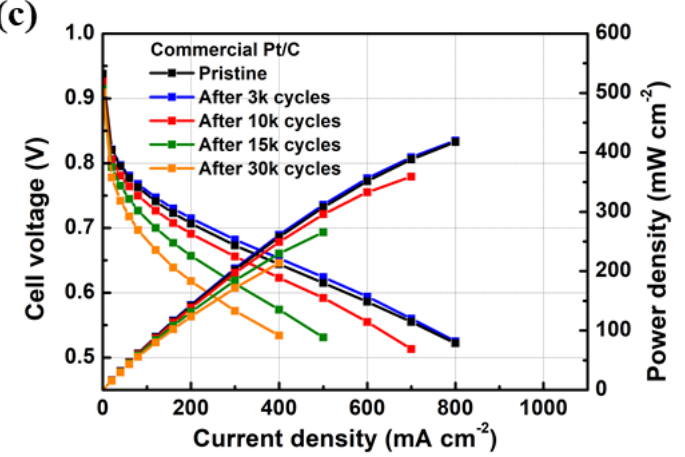

(b)

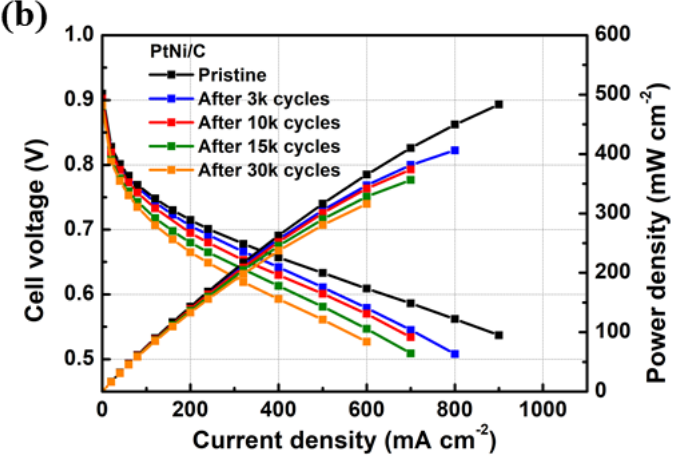

(d)

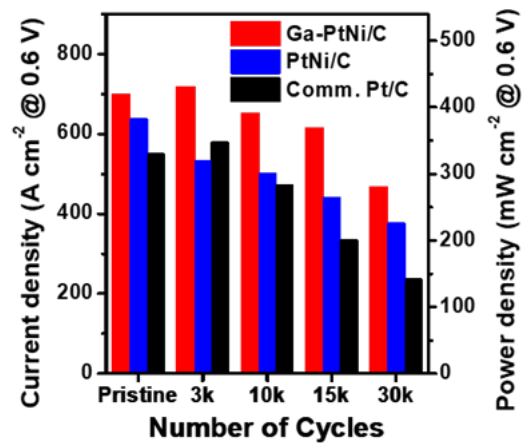

Figure 6. Single-cell performance and long-term durability of the fabricated MEAs with Ga$\mathrm{PtNi} / \mathrm{C}, \mathrm{PtNi} / \mathrm{C}$, and commercial $\mathrm{Pt} / \mathrm{C}$ as a cathode catalyst with $\mathrm{Pt}$ loading of $0.15 \mathrm{mgt}_{\mathrm{Pt}} \mathrm{cm}^{-2}$ (anode catalyst was the commercial $\mathrm{Pt} / \mathrm{C}$ with $\mathrm{Pt}$ loading of $0.15 \mathrm{mgt}_{\mathrm{Pt}} \mathrm{cm}^{-2}$ ). Polarization curves for the single cells using (a) Ga-PtNi/C, (b) PtNi/C and (c) commercial Pt/C recorded before and after 3k, 10k, 15k and 30k cycles. (d) Current density (left) and power density (right) at $0.6 \mathrm{~V}$ of $\mathrm{Ga}-\mathrm{PtNi} / \mathrm{C}, \mathrm{PtNi} / \mathrm{C}$, and commercial Pt/C. The single-cells were operated at $65{ }^{\circ} \mathrm{C}$ with feeding fully humidified hydrogen and air to the anode and cathode, respectively, without backpressure. 
Table 1. Electrochemical performance of Ga-PtNi/C, PtNi/C and the commercial $\mathrm{Pt} / \mathrm{C}$ measured via half-cell and single-cell tests.

\begin{tabular}{lccccc}
\hline & $\begin{array}{c}\text { Mass activity } \\
{\left[\mathrm{A} \mathrm{mg \textrm {mt } ^ { - 1 }}\right.} \\
\left.@ 0.9 \mathrm{~V}_{\mathrm{RHE}}\right]\end{array}$ & $\begin{array}{c}\mathrm{ECSA} \\
{\left[\mathrm{m}^{2} \mathrm{gPt}^{-1}\right]}\end{array}$ & $\begin{array}{c}\text { Specific activity } \\
{\left[\mathrm{mA} \mathrm{cm}^{-2}\right.} \\
\left.@ 0.9 \mathrm{~V}_{\mathrm{RHE}}\right]\end{array}$ & $\begin{array}{c}\text { Current density } \\
{\left[\mathrm{mA} \mathrm{cm}^{-2}\right.} \\
@ 0.6 \mathrm{~V}]\end{array}$ & $\begin{array}{c}\text { Power density } \\
{\left[\mathrm{mW} \mathrm{cm}^{-2}\right.} \\
@ 0.6 \mathrm{~V}]\end{array}$ \\
\hline $\mathrm{Ga}-\mathrm{PtNi} / \mathrm{C}$ & 1.24 & 49 & 2.53 & 700 & 420 \\
$\mathrm{PtNi} / \mathrm{C}$ & 0.464 & 49 & 0.947 & 639 & 383 \\
$\mathrm{Pt} / \mathrm{C}$ & 0.106 & 74 & 0.146 & 552 & 331 \\
& & & & &
\end{tabular}

\section{CONCLUSIONS}

Ga-doped PtNi octahedral nanoparticles were synthesized with a well-extended (111) facet and a uniform distribution on a carbon support. The Ga-PtNi/C showed excellent ORR activity and stability compared to PtNi/C and commercial Pt/C. The initial ORR activities of the Ga$\mathrm{PtNi} / \mathrm{C}\left(1.24 \mathrm{~A} \mathrm{mg} \mathrm{Pt}^{-1}\right.$ ) were 2.7 and 11.7 times higher than those of $\mathrm{PtNi} / \mathrm{C}$ and $\mathrm{Pt} / \mathrm{C}$, respectively. DFT calculations revealed that the oxygen intermediate binding energy of PtNi was modulated by Ga doping toward the optimal value. After 30k cycles in a half cell, the Ga$\mathrm{PtNi} / \mathrm{C}$ showed mass activity of $0.428 \mathrm{~A} \mathrm{mgpt}^{-1}$, higher than that of $\mathrm{PtNi} / \mathrm{C}\left(0.009 \mathrm{~A} \mathrm{mget}^{-1}\right)$ and $\mathrm{Pt} / \mathrm{C}\left(0.019 \mathrm{~A} \mathrm{mg}_{\mathrm{Pt}}{ }^{-1}\right)$. During the 30k cycles, the Ni content decreased from 38 to 30 at \% in Ga-PtNi nanoparticles while from 40 to 10 at \% in PtNi nanoparticles. The majority of Ga-PtNi maintained an octahedral shape after 30k cycles, while most of the PtNi nanoparticles completely lost their shape after $4 \mathrm{k}$ cycles. The electrochemical, compositional, and structural stability of the Ga-PtNi/C could be associated with the reduced oxophilic surface and lattice compression induced by Ga doping. 
The performance and durability of single cells fabricated with $\mathrm{Ga}-\mathrm{PtNi} / \mathrm{C}$ were evaluated in comparison with those of $\mathrm{PtNi} / \mathrm{C}$ and commercial Pt/C. With a current density at $0.6 \mathrm{~V}$, GaPtNi/C exhibited higher initial performance than PtNi/C and Pt/C. At 15k cycles, Ga-PtNi/C lost $12 \%$ of its initial performance, whereas PtNi/C and Pt/C lost $31 \%$ and $39 \%$, respectively. The majority of Ga-PtNi nanoparticles well maintained the octahedral shape without severe agglomeration even after 30k cycles in single cell durability test. In conclusion, Ga-PtNi/C is presented as a highly active and robust ORR catalyst with verified performance and durability through half-cell and full cell tests. 


\begin{abstract}
ASSOCIATED CONTENT
Conflict of Interest: The authors declare no competing financial interest.

Supporting Information: The following files are available free of charge on the ACS

Publications website at DOI:

More characterization and electrochemical details including ICP, XRD, CO-stripping, XPS,

HR-TEM, EXAFS, and DFT calculation (Figures S1-S10, Tables S1-S6).
\end{abstract}

\title{
AUTHOR INFORMATION
}

\section{Corresponding Author}

*E-mail: eacho@kaist.ac.kr

\section{ACKNOWLEDGMENT}

This work was supported by Korea Institute of Energy Technology Evaluation and Planning (KETEP) under contract No. 20143030031340 and Korea Institute of Science and Technology (KIST) under contract No. 2016940826. 


\section{REFERENCES}

1. De Bruijn, F.; Dam, V.; Janssen, G. Fuel cells 2008, 8, (1), 3-22.

2. Kim, M.; Nam, D.-H.; Park, H.-Y.; Kwon, C.; Eom, K.; Yoo, S.; Jang, J.; Kim, H.-J.; Cho, E.; Kwon, H. Journal of Materials Chemistry A 2015, 3, (27), 14284-14290.

3. Greeley, J.; Stephens, I.; Bondarenko, A.; Johansson, T. P.; Hansen, H. A.; Jaramillo, T.; Rossmeisl, J.; Chorkendorff, I.; Nørskov, J. K. Nature chemistry 2009, 1, (7), 552-556.

4. Oh, S.; Kim, J.; Kim, M.; Nam, D.; Park, J.; Cho, E.; Kwon, H. Journal of Materials Chemistry $A$ 2016, 4, (37), 14400-14407.

5. Han, B.; Carlton, C. E.; Kongkanand, A.; Kukreja, R. S.; Theobald, B. R.; Gan, L.; O'Malley, R.; Strasser, P.; Wagner, F. T.; Shao-Horn, Y. Energy \& Environmental Science 2015, 8, (1), 258-266.

6. Wang, Y.-J.; Zhao, N.; Fang, B.; Li, H.; Bi, X. T.; Wang, H. Chemical reviews 2015, 115, (9), 3433-3467.

7. Jung, N.; Chung, D. Y.; Ryu, J.; Yoo, S. J.; Sung, Y.-E. Nano Today 2014, 9, (4), 433-456.

8. Jung, C.; Lee, C.; Bang, K.; Lim, J.; Lee, H.; Ryu, H. J.; Cho, E.; Lee, H. M. ACS Applied Materials \& Interfaces 2017.

9. Choi, D. S.; Robertson, A. W.; Warner, J. H.; Kim, S. O.; Kim, H. Advanced Materials 2016, 28, (33), 7115-7122.

10. Chattot, R.; Asset, T.; Drnec, J.; Bordet, P.; Nelayah, J.; Dubau, L.; Maillard, F. Nano Letters 2017, 17, (4), 2447-2453.

11. Huang, X.; Zhao, Z.; Chen, Y.; Zhu, E.; Li, M.; Duan, X.; Huang, Y. Energy \& Environmental Science 2014, 7, (9), 2957-2962.

12. Gan, L.; Heggen, M.; Cui, C.; Strasser, P. ACS catalysis 2015, 6, (2), 692-695.

13. Chen, C.; Kang, Y.; Huo, Z.; Zhu, Z.; Huang, W.; Xin, H. L.; Snyder, J. D.; Li, D.; Herron, J. A.; Mavrikakis, M. Science 2014, 343, (6177), 1339-1343.

14. Cui, C.; Gan, L.; Li, H.-H.; Yu, S.-H.; Heggen, M.; Strasser, P. Nano letters 2012, 12, (11), $5885-$ 5889.

15. Zhang, J.; Yang, H.; Fang, J.; Zou, S. Nano Lett 2010, 10, (2), 638-644.

16. Gan, L.; Heggen, M.; Rudi, S.; Strasser, P. Nano letters 2012, 12, (10), 5423-5430.

17. Koh, S.; Strasser, P. Journal of the American Chemical Society 2007, 129, (42), 12624-12625.

18. Wang, D.; Xin, H. L.; Hovden, R.; Wang, H.; Yu, Y.; Muller, D. A.; DiSalvo, F. J.; Abruña, H. D. Nature materials 2013, 12, (1), 81-87.

19. Chen, S.; Ferreira, P. J.; Sheng, W.; Yabuuchi, N.; Allard, L. F.; Shao-Horn, Y. Journal of the American Chemical Society 2008, 130, (42), 13818-13819.

20. Stamenkovic, V. R.; Fowler, B.; Mun, B. S.; Wang, G.; Ross, P. N.; Lucas, C. A.; Marković, N. M. 
science 2007, 315, (5811), 493-497.

21. Kitchin, J.; Nørskov, J. K.; Barteau, M.; Chen, J. The Journal of chemical physics 2004, 120, (21), 10240-10246.

22. Stamenkovic, V.; Mun, B. S.; Mayrhofer, K. J.; Ross, P. N.; Markovic, N. M.; Rossmeisl, J.; Greeley, J.; Nørskov, J. K. Angewandte Chemie 2006, 118, (18), 2963-2967.

23. Mukerjee, S.; Srinivasan, S.; Soriaga, M. P.; McBreen, J. Journal of the Electrochemical Society 1995, 142, (5), 1409-1422.

24. Kavian, R.; Choi, S.-I.; Park, J.; Liu, T.; Peng, H.-C.; Lu, N.; Wang, J.; Kim, M. J.; Xia, Y.; Lee, S. W. Journal of Materials Chemistry A 2016, 4, (32), 12392-12397.

25. Carpenter, M. K.; Moylan, T. E.; Kukreja, R. S.; Atwan, M. H.; Tessema, M. M. Journal of the American Chemical Society 2012, 134, (20), 8535-8542.

26. Sha, Y.; Yu, T. H.; Merinov, B. V.; Shirvanian, P.; Goddard III, W. A. The Journal of Physical Chemistry C 2012, 116, (40), 21334-21342.

27. Arán-Ais, R. M.; Dionigi, F.; Merzdorf, T.; Gocyla, M.; Heggen, M.; Dunin-Borkowski, R. E.; Gliech, M.; Solla-Gullón, J.; Herrero, E.; Feliu, J. M. Nano letters 2015, 15, (11), 7473-7480.

28. Cui, C.; Gan, L.; Heggen, M.; Rudi, S.; Strasser, P. Nature materials 2013, 12, (8), 765-771.

29. Beermann, V.; Gocyla, M.; Willinger, E.; Rudi, S.; Heggen, M.; Dunin-Borkowski, R. E.; Willinger, M.-G.; Strasser, P. Nano letters 2016, 16, (3), 1719-1725.

30. Huang, X.; Zhao, Z.; Cao, L.; Chen, Y.; Zhu, E.; Lin, Z.; Li, M.; Yan, A.; Zettl, A.; Wang, Y. M. Science 2015, 348, (6240), 1230-1234.

31. Gatalo, M.; Jovanovič , P.; Polymeros, G.; Grote, J.-P.; Pavliš ič , A.; Ruiz-Zepeda, F.; S` elih, V. S.; Šala, M.; Hočevar, S.; Bele, M. ACS Catalysis 2016, 6, (3), 1630-1634.

32. Li, Y.; Quan, F.; Chen, L.; Zhang, W.; Yu, H.; Chen, C. RSC Advances 2014, 4, (4), 1895-1899.

33. Chen, S.; Gasteiger, H. A.; Hayakawa, K.; Tada, T.; Shao-Horn, Y. Journal of the Electrochemical Society 2010, 157, (1), A82-A97.

34. Carlton, C. E.; Chen, S.; Ferreira, P. J.; Allard, L. F.; Shao-Horn, Y. The Journal of Physical Chemistry Letters 2012, 3, (2), 161-166.

35. Xin, H. L.; Mundy, J. A.; Liu, Z.; Cabezas, R.; Hovden, R.; Kourkoutis, L. F.; Zhang, J.; Subramanian, N. P.; Makharia, R.; Wagner, F. T. Nano letters 2011, 12, (1), 490-497.

36. Kumar, V. B.; Sanetuntikul, J.; Ganesan, P.; Porat, Z. e.; Shanmugam, S.; Gedanken, A. Electrochimica Acta 2016, 190, 659-667.

37. Studt, F.; Sharafutdinov, l.; Abild-Pedersen, F.; Elkjær, C. F.; Hummelshøj, J. S.; Dahl, S.; Chorkendorff, I.; Nørskov, J. K. Nature chemistry 2014, 6, (4), 320-324.

38. Albiter, A.; Espinosa-Medina, M.; Gonzalez-Rodriguez, J.; Perez, R. International journal of hydrogen energy 2005, 30, (12), 1311-1315.

39. Schmidt, T.; Gasteiger, H.; Stäb, G.; Urban, P.; Kolb, D.; Behm, R. Journal of The Electrochemical Society 1998, 145, (7), 2354-2358. 
40. Choi, J.; Lee, Y.; Kim, J.; Lee, H. Journal of Power Sources 2016, 307, 883-890.

41. Colón-Mercado, H. R.; Kim, H.; Popov, B. N. Electrochemistry Communications 2004, 6, (8), 795-799.

42. Niu, G.; Zhou, M.; Yang, X.; Park, J.; Lu, N.; Wang, J.; Kim, M. J.; Wang, L.; Xia, Y. Nano letters 2016, 16, (6), 3850-3857.

43. Gan, L.; Cui, C.; Heggen, M.; Dionigi, F.; Rudi, S.; Strasser, P. Science 2014, 346, (6216), 15021506.

44. Wang, R.; Xu, C.; Bi, X.; Ding, Y. Energy \& Environmental Science 2012, 5, (1), 5281-5286.

45. Min, M.-k.; Cho, J.; Cho, K.; Kim, H. Electrochimica Acta 2000, 45, (25), 4211-4217.

46. Ho, V. T. T.; Pan, C.-J.; Rick, J.; Su, W.-N.; Hwang, B.-J. Journal of the American Chemical Society 2011, 133, (30), 11716-11724.

47. Sasaki, K.; Naohara, H.; Choi, Y.; Cai, Y.; Chen, W.-F.; Liu, P.; Adzic, R. R. Nature communications 2012, 3, 1115.

48. Park, K.-W.; Seol, K.-S. Electrochemistry Communications 2007, 9, (9), 2256-2260.

49. Zhang, J.; Sasaki, K.; Sutter, E.; Adzic, R. Science 2007, 315, (5809), $220-222$.

50. Jia, Q.; Zhao, Z.; Cao, L.; Li, J.; Ghoshal, S.; Davies, V.; Stavitski, E.; Attenkofer, K.; Liu, Z.; Li, M. Nano letters 2017.

51. Nørskov, J. K.; Rossmeisl, J.; Logadottir, A.; Lindqvist, L.; Kitchin, J. R.; Bligaard, T.; Jonsson, H. The Journal of Physical Chemistry B 2004, 108, (46), 17886-17892.

52. Zhang, Y.; Duan, Z.; Xiao, C.; Wang, G. Surface Science 2011, 605, (15), 1577-1582.

53. Torelli, D. A.; Francis, S. A.; Crompton, J. C.; Javier, A.; Thompson, J. R.; Brunschwig, B. S.; Soriaga, M. P.; Lewis, N. S. Acs Catalysis 2016, 6, (3), 2100-2104. 